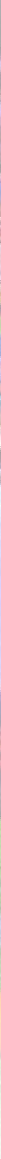

Dr. Németh András* - Virágh Krisztián**

\title{
Virtuális valóság és haderő - polgári alkalmazási lehetőségek m.r.resz
}

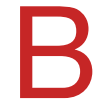
ár a virtuális valóság (VR - Virtual Reality) nem a 21. század találmánya, a technológia csak az elmúlt évtizedben érte el azt a fejlettségi szintet, ami megteremtette szélesebb körű elterjedésének technikai feltételeit. Az utca embere ma még csak többnyire filmekben, illetve VR-vidámparkokban, vagy szórakoztatóközpontokban találkozhat fejlettebb virtuális élményt kínáló megoldásokkal, ugyanakkor néhány százezer forintos befektetéssel már az otthonunkban is megtapasztalhatjuk a technológiában rejlő lehetőségeket. A katonai kiképzés területén a VR számos elemét használják már akár évtizedek óta, a komplex, magas valóságérzetet keltő megoldások integrációja mégis további, nagy dinamikával fejlődő lehetőséget kínál a hazai kiképzés rendszerének reformjára és folyamatos modernizálására. A sorozat korábbi részeiben a szerzők a VR történetét, fejlődését és az immerzitásélmény folyamatos fokozásához szükséges technológiai hátteret mutatták be.

\section{ÚJ TÁVLATOK A VIRTUÁLIS TÉRBEN}

A 20. században számos olyan korszakalkotó találmányt fejlesztettek ki katonai célokra, amelyek később fokozatosan jelentek meg különböző polgári alkalmazási területe- ken is, majd ott is teljesedtek ki igazán. Ennek egyik leglátványosabb példája maga a világháló, az internet. Ezzel szemben a virtuális valóság, illetve kiterjesztett valóság (AR - Augmented Reality) fejlődése során már a kezdetektől fogva a civil alkalmazási lehetőségek domináltak, és csak később alakult ki egy párhuzamos, kifejezetten katonai célú irányvonal. Noha a VR ma még nem szerves része az emberek mindennapi életének, a technológiát már számos területen alkalmazzák különböző speciális részfeladatok végrehajtásának hatékonyságnövelése érdekében. A kifejezést meghallva valamilyen újkeletü, modern eszközre vagy programra gondolhatunk, amit a legtöbben a szórakoztatóiparhoz, azon belül a számítógépes és konzoljátékok világához, esetleg a filmiparhoz társítanak. Ez a tény nem meglepő, hiszen a VR alkalmazási lehetőségei közül ezek a média által leggyakrabban említett területek. A VR azonban több annál, mint a játékiparban használatos hardver- és szoftvertechnológiák összessége, mára a felhasználás lehetőségeinek csak töredéke kapcsolódik ehhez a területhez. Az alkalmazás széleskörü terjedésével a VR új távlatokat nyitott például a számítógépes tervezés, az építészet, az orvoslás, az oktatás, a sport, a régészet, vagy éppen a műszaki képzés, üzemeltetés és karbantartás világában. A dróngyártáshoz hasonlóan, a gyorsuló technikai

* Alezredes, tanszékvezető, egyetemi docens, NKE Hadtudományi és Honvédtisztképző Kar, Elektronikai Hadviselés Tanszék, ORCID: 0000-0003-2397-189X

** Tanszéki mérnök, NKE Hadtudományi és Honvédtisztképző Kar, Elektronikai Hadviselés Tanszék, ORCID: 0000-0003-4184-9492 
fejlődés és piaci verseny következtében bővülő termékkínálat, és a folyamatosan megújuló megoldásoknak köszönhetően, a virtuális valóság is fokozatosan önálló iparággá válik. Ez a tendencia abba az irányba mutat, hogy a technológia hamarosan utat tör magának az élet csaknem minden területén. A fejlődés útjában nem állnak a pilóta nélküli légijármű-rendszerek alkalmazását korlátozó egyébként teljesen jogos, de sokszor vitatható mértékü bürokratikus szabályozáshoz hasonló akadályok, miközben, többek között a ma már igazolható hatékonyságnövelő hatásnak köszönhetően, az igény rohamosan növekszik. Tanulmányunk jelen részében a teljesség igénye nélkül, különböző polgári területeken történő alkalmazási lehetőségeket mutatunk be, előre bocsátva, hogy ezek jelentős része a katonai tevékenységekkel összefüggő feladatok ellátása során is kínálhat hatékony alternatívát a hagyományos megoldásokkal szemben.

\section{SZÓRAKOZTATÓIPAR}

A VR-technológiát napjainkban ez a terület használja a legnagyobb mértékben, és ezen belül - az eszközök árában bekövetkező csökkenésnek köszönhetően - a játékipar tekinthető a húzóágazatna. Ennek fő oka, hogy a feltörekvő startup vállalkozások mellett több nagyvállalat, mint például a Google, a Microsoft, a Samsung vagy a Sony is gyárt és forgalmaz VR-termékeket, hardverelemeket. Elsősorban ezen cégek marketingtevékenysége miatt kapnak kiemelt figyelmet az újgenerációs, VR-környezetben is játszható játékok, amelyek lényege, hogy a játékos, különböző eszközök használatának segítségével, minél jobban belemerüljön a virtuális világba. A VR-eszközök közül jelenleg a fejre helyezhető kijelzők (HMD - Head Mounted Display) rendelkeznek az egyik legnagyobb piaccal. 2016ban, amikor a VR fokozatosan a figyelem középpontjába került, már több milliót adtak el csak HMD készülékekből, azonban mostanáig nem tapasztalhattunk kiemelkedően magas növekedést az eszközök eladásaiban. Ugyanakkor átrendeződés figyelhető meg a termékkínálatban: míg kezdetben az okostelefonokhoz gyártott AR/VR HMD-k domináltak, mára a konzolos és számítógépes eszközök iránti kereslet erősödését tapasztalhatjuk. [48] A piaci folyamatokat elemezve, mint ahogy az a 28. ábrán is megfigyelhe-

28. ábra. AR és VR HMD készülékek várható értékesítése (a szerzők szerkesztése [50] alapján)

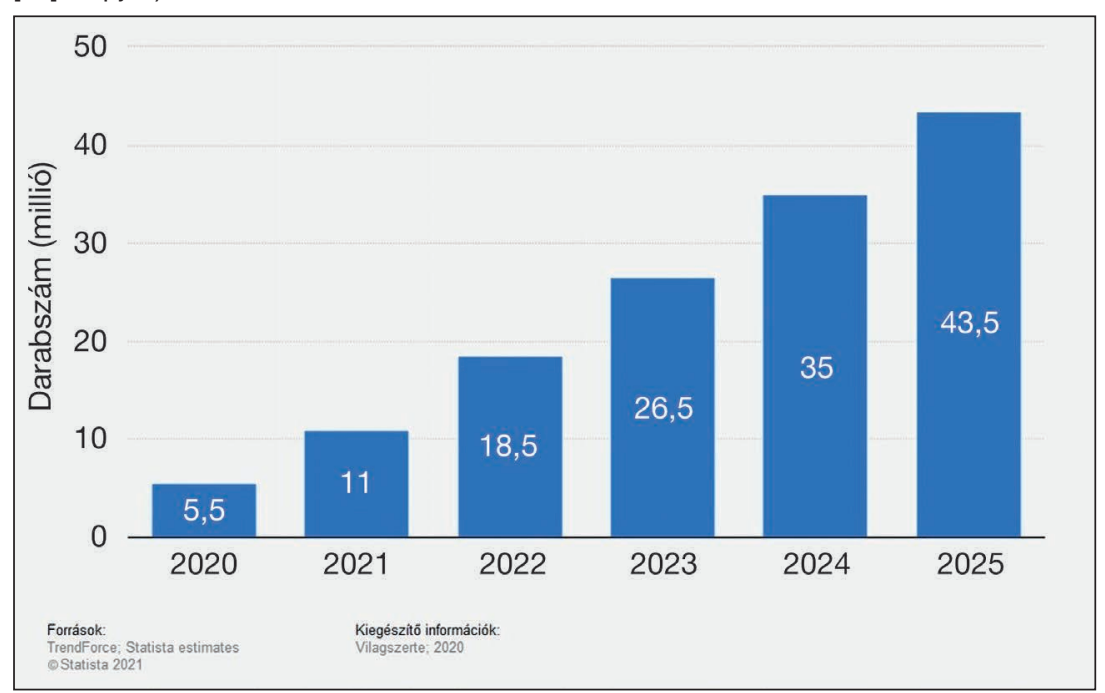

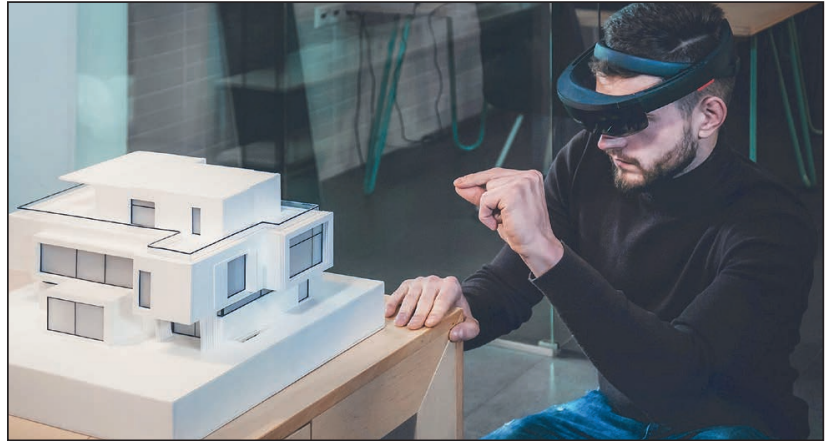

29. ábra. Virtuális modellezés az építészetben [53]

tő, a következő években a HMD-k értékesítésének dinamikus növekedése prognosztizálható. [49]

A technológiai fejlődés a jövőben jelentősen átalakíthatja majd mind a számítógépes játékok, mind pedig a filmipar piacát. Jelenleg még viszonylag kevés VR-ral támogatott számítógépes vagy konzolos játék érhető el, aminek oka, hogy a nagy technológiai vállalatok nem kívánnak addig nagyobb összeget befektetni a virtuális valóság hardverelemeinek korszerűsítésébe, amíg a játékfejlesztő cégek nem gyártanak virtuális valóság tartalommal felruházott játékokat. Ebből a látszólagos patthelyzetből tört ki a Facebook az Oculus HMD-jének folyamatos fejlesztésével, amelynek köszönhetően mára a virtuális élmény immerzivitása (valóságérzet) jelentősen javult. A sikerek hatására egyre több gyártó fektet be a VR-eszközök innovációjába, ezért az otthoni felhasználásra szánt eszközök piacán fokozódó versenyt figyelhetünk meg. A filmiparban még csak mostanában kezdték el forgatni az első VR-filmeket, amelyek a megszokottól teljesen eltérő, immerzív filmélményt adhatnak majd a nézőknek azáltal, hogy ők is az adott alkotás „résztvevői” lehetnek. [51] Érdemes lesz követni az elkövetkezendő évek filmes eseményeit, mert a közeljövőben egyre több VR-film bemutatására kerül sor. Az új technológiával készített alkotások már a filmszakma egy új korszakát jelzik.

\section{É́fitészet}

Az elmúlt évek professzionális, munkaeszközként történő felhasználási módjainak terjedését tekintve talán az építészet az egyik legdinamikusabban fejlődő ágazat, ahol már régóta használnak integrált virtuális modellezési platformokat (29. ábra) különböző tervezési feladatkhoz. [52]

Ezenkívül egy újabb alkalmazás is egyre nagyobb teret hódít, amely nem az építő- és építészmérnökök tervezőmunkáját segíti, hanem az ingatlanpiaci szereplőknek, közvetítőknek, marketing szakembereknek és üzleti partnereknek kínál szolgáltatásbővítési lehetőséget (30. ábra). Ennek lényege, hogy a mérnökök által megtervezett épületek, vagy az eladásra kínált ingatlanok virtuális modelljeit az ügyfelek testközelből tekinthetik meg, illetve járhatják be a VRszemüvegek és -sisakok segítségével. Ennek egy egyszerüsített változata, amikor nem a virtuális modelleket, 


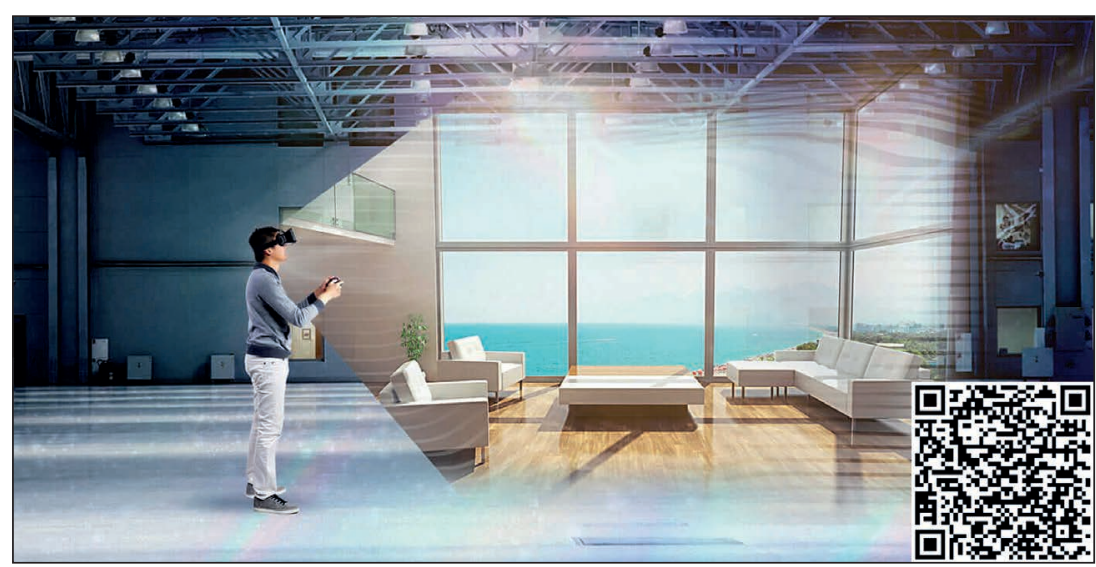

30. ábra. A VR szerepe az építészetben és a marketingben is növekszik [54]

esetleges hiba kockázatát. Ezzel az eljárással bonyolultabb beavatkozások esetén, még tapaszalt szakorvosoknál is jelentősen javítható lenne az eredményességi mutató, és így a betegek gyógyulási esélyei is növekednének. Az orvostanhallgatók számára ugyanakkor a VR nemcsak egy-egy konkrét beavatkozást megelőző felkészülésben, de a képzés teljes időszaka alatt jelenthet segítséget, folyamatos gyakorlási és hatékony tanulási platformot. (31. ábra.) Nemcsak az emberi test felépítését, működését lehet a hagyományos módszereknél lényegesen gyorsabban megérteni, illetve elsajátítani, de a hallgatók akár közvetlen szakorvosi felügyelet nélkül is vizsgálatokat végezhetnek, il-

hanem az ingatlanokban készített fényképsorozatok elemeit vetítik ki a megjelenítő eszközre a szemlélő fejének orientációjához igazítva, ezáltal keltve térbeli hatást, így a felhasználó egy virtuális séta keretében tekintheti meg az épületeket. Ennek a technikai megoldásnak a piaca az elmúlt évben kialakult járványügyi veszélyhelyzet hatására jelentősen fellendült, ugyanis e technológia biztosítja egy ingatlanba történő betekintés egyik leginformatívabb, személyes jelenlétet nem igénylő formáját az online térben.

\section{ORVOSTUDOMÁnY}

Ezen a területen rendkívül nagy potenciál mutatkozik az orvos- és szakszemélyzethiány korában, amelyet az emberi életek megóvása, valamint az egészségügyi, gyógyító szolgáltatások színvonalának emelése érdekében, a jövőben mindenképpen egyre szélesebb körben ki kell aknázni. Például a különböző műtétek megtervezéséhez az orvosok fejlettebb kórházakban, magánegészségügyi intézményekben már napjainkban is sok esetben vesznek igénybe 3D-s modellező programokat. Ezek használatának egyik éllovasa a plasztikai sebészet, hiszen ilyen megoldások segítségével a műtét várható eredményét előre lehet egyeztetni a pácienssel. Ugyanakkor az alkalmazások területén hatékony fejlesztési irányzat lenne az is, ha a mútétek megtervezésén túl az orvostanhallgatók, vagy kezdő orvosok a betegek virtuális modelljein, még a tényleges beavatkozás előtt elvégezhetnék a mútéteket, ezáltal csökkentve egy

\section{1. ábra. VR-eszközök alkalmazása az orvoslásban [56]}

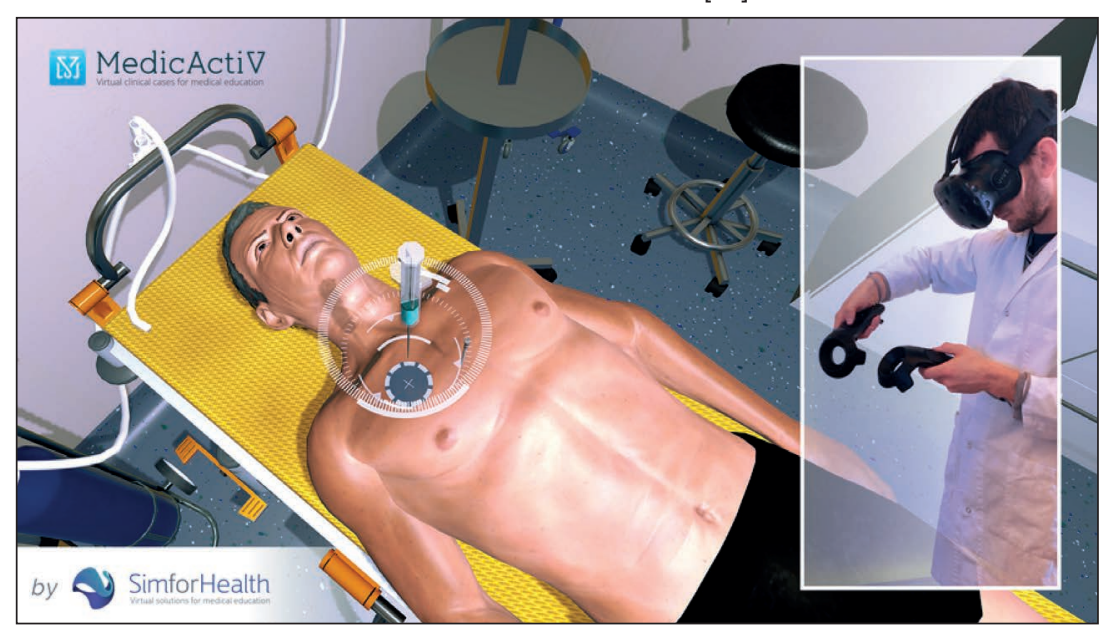

letve műtéteket is végrehajthatnak különböző fizikai adottságokkal rendelkező, eltérő egészségi állapotú, nemű és korú virtuális pácienseken. Ezenfelül természetesen csaknem minden orvosi szakterületen lehetséges a virtuális, vagy kiterjesztett valóság alapú megoldások gyógyítási rendszerbe történő integrálása. Ma már az ortopédiában, valamint a pszichológián belül, a különböző fóbiák gyógyításában is találkozhatunk ilyen példákkal. A jövőben ugyanakkor akár olyan komoly betegségek gyógyításához is hozzájárulhat majd ez a technológia, mint az autizmus, a memóriazavar, vagy egyéb mentális betegségek. [55] lzgalmas kutatási terület lehet még a különböző alkalmassági vizsgálatok során történő felhasználás lehetősége, amelyek egyes szegmenseit akár forradalmasítani is lehetne VR-eszközök használatával. Például a jogosítvány megszerzéséhez szükséges vizsgálatokat ki lehetne egészíteni virtuális szimulációs feladatokkal, amelyekkel ellenőrizhető, hogy rendelkezik-e a vizsgázó a megfelelő reflexekkel, döntéshozatali készségekkel.

\section{OKTATÁS}

„Általánosságban megfogalmazható, hogy a korszerű, szofisztikált rendszerek - mint például a szimulátorok - alkalmazása a modern oktatási felfogás és a haladó gondolkodás ismérvei kell, hogy legyenek minden szervezetnél. Meglátásom szerint az ilyen megoldások alkalmazása során az oktató (kiképző) a tradicionális, vagy konzervatív oktatási módszerekkel szemben, aktívan bevonja a hallgatókat a tudásátadás folyamatába. Erre egyre nagyobb igény jelentkezik, ugyanis a hálózatalapú társadalom kialakulása, a világ folyamatainak felgyorsulása miatt a hagyományos nevelési-oktatási eljárások már nem elegendőek a diákok figyelmének a lekötéséhez, és ezáltal a tananyag megfelelő szinten történő átadásához. Ezért van szükség egyre komplexebb ingereket generáló módszerre..." [57] A fenti követelménynek a virtuálisvalóság-rendszerek is megfelelhetnek logikusan felépített és igényesen kidolgozott tartalmak, oktatóanyag felhasználása esetén. Képzeljünk el egy olyan történelemórát, ahol a diákok a nándorfehérvári diadalt, a középkori életmódot, vagy éppen Napóleon waterlooi csatáját nemcsak a tanár 


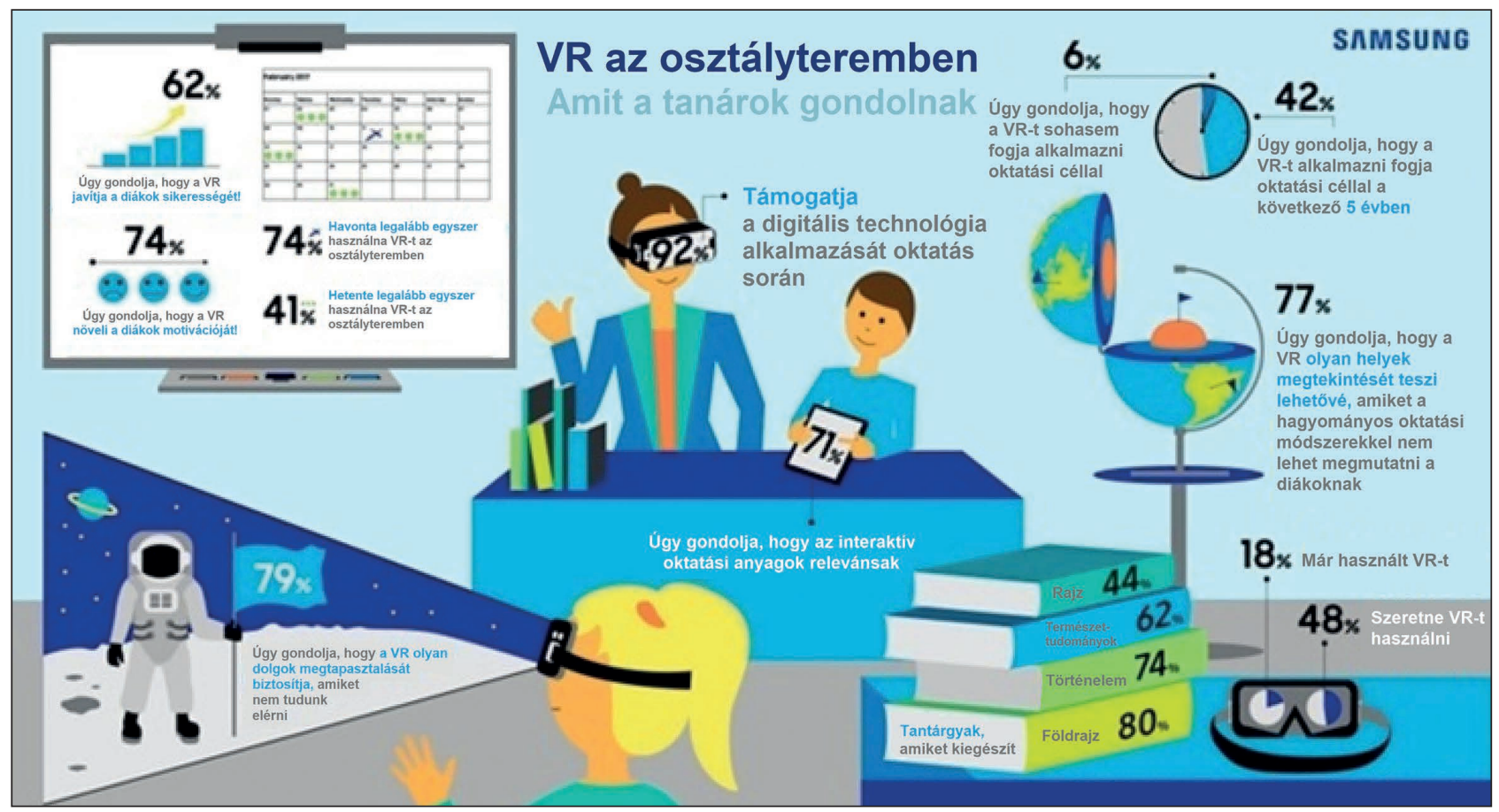

32. ábra. A német Kantar EMNID közvélemény-kutató cég tanárok körében végzett kutatási eredményeit bemutató infografika (a [62] alapján a szerzők szerkesztése)

szavaiból ismerik meg, hanem ténylegesen ott érezhetik magukat az adott korban és helyszínen. A matematikaórák is élvezhetőbbé tehetők, hiszen a VR segíthet jobban megérteni például a térgeometriai feladatokat, vagy éppen a vektorterek tárgykörét. Általánosságban elmondható, hogy minden oktatási szinten és az összes tantárgy esetén felhasználható ez a technológia a tudásátadás hatásfokának növelésére. A VR-rendszerek biztosítják a legkézenfekvőbb megoldást az élményalapú oktatás és a kreatív tanulási módszerek [58] széles körű elterjesztésére.

Célszerű külön kiemelni a távoktatás területét. Az elméleti tananyagok elsajátításához nem kell feltétlenül jelenléti formában személyes kontaktust fenntartani a tanár és diák között (bár ez jelentősen növeli az oktatási tevékenység hatásfokát), léteznek azonban olyan gyakorlati ismeretek, amelyek esetén ez ma még elengedhetetlen (például laboratóriumi mérések, üzemeltetési gyakorlatok, kísérletek). A VR-technológiának köszönhetően virtuális osztálytermekben vehetünk részt a tanórákon, és mivel ma már a virtuális objektumokkal is egyre táguló keretek között léphetünk interakcióba, így egyes gyakorlati foglalkozások megtartására is lehetőség nyílik. A különböző online kurzusok is gyakorlatorientáltabbak lehetnek, így akár fel is értékelődhetnek az ilyen formában szerzett képesítések. Természetesen a valós eszközökkel végrehajtott gyakorlati foglalkozások és laborgyakorlatok az új technológia mellett sem nélkülözhetők, arányuk, és ezáltal költségük ugyanakkor a teljes képzési időre vonatkoztatva jelentősen csökkenthető.

További jelentős fejlődés érhető el az oktatási rendszer egészét tekintve, ha az új technológia által kínált lehetőségeket egy olyan alternatív oktatási stratégiába illesztjük be, amely a jelenleginél lényegesen nagyobb hangsúlyt fektet a diákok egyéni képességeinek fejlesztésére. A differenciált oktatás nagyságrendekkel hatékonyabb, ugyanakkor lényegesen erőforrásigényesebb pedagógiai módszer, mint a „porosz” oktatási rendszer, amely a mai napig meghatározza a magyar közoktatást, és amelynek központi eleme az uniformizált, frontális ismeretátadás. [59] Nem- csak társadalmi igény, de az ország versenyképessége szempontjából is fontos szükséglet az idejétmúlt oktatási módszerek háttérbe szorítása, amelyre történelmi lehetőséget a tavalyi évben - éppen a járvány okozta veszélyhelyzet miatt - bevezetett számos korlátozás, és a digitális oktatásra történő kényszerű áttérés kínálja. A gyakorlatban történő megvalósításhoz ugyanakkor ennél lényegesen nagyobb léptékben kell gondolkodni, hiszen egy valódi reformhoz egyrészt az oktatási infrastruktúra minden elemének egységes szempontrendszer szerinti korszerűsítésére, másrészt a pedagógushiány jelentős mérséklésére van szükség, és csak ezután lehet rendszer szinten áttérni a lényegesen hatékonyabb módszerek alkalmazására. Mind a három területen előrelépést, részleges, vagy akár teljes megoldást is jelenthet a VR-technológia oktatásba történő minél szélesebb körü bevonása. Érdemes kiemelt figyelmet fordítani a VR nyújtotta lehetőségek és a tanárhiány kapcsolatára. Napjainkra a tanári hivatás presztízse jelentősen megkopott, így a fiatalok körében a legkevésbé népszerü karrierutak közé tartozik. A társadalmi és anyagi megbecsülés hiánya miatt már az elmúlt évtizedben sem volt biztosított az az egészséges körforgás, amelynek keretében a nyugdíjba vonuló tanárok helyét fokozatosan fiatal pedagógusok veszik át. [60] Ez az anomália természetesen visszahat, és fékezi a korszerű oktatási módszerek bevezetését is, ami viszont tovább csökkenti a tanári pálya vonzerejét. Ebből az ördögi körből a VR-technológiára épülő mesterséges intelligencia (Al - Artificial Intelligence) alapú oktatási platformok jelenthetnek kiutat a jövőben, amelyek egyre növekvő számú feladatot lesznek képesek átvenni a tanároktól. [61] A tanár személyének háttérbe szorulása természetesen sem módszertanilag, sem pedig emberileg nem jelent ideális állapotot, hiszen sokszor egy adott témakört vagy tantárgyat az oktató személye tesz vonzóvá, élvezhetővé a diákok számára, ugyanakkor a jelenlegi tendencia szerint kénytelenek leszünk alternatív módszert kifejleszteni az oktatási rendszer működőképességének fenntartása érdekében. 


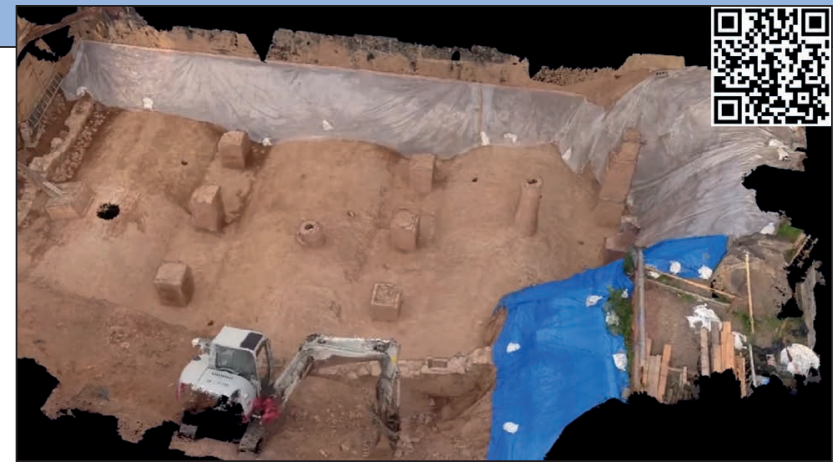

A VR-rendszerek alkalmazását szakmai szempontból maguk a tanárok is támogatják. A német Kantar EMNID cég által végzett közvélemény-kutatás keretében 606 tanárt véleményét kérdezték meg. Válaszaik eredményeit a 32. ábrán látható infografika foglalja össze. Ebből egyértelműen leolvasható, hogy a megkérdezettek nagy többsége (több mint 90\%-a) támogatja a VR-ral kiegészített oktatási módszerek bevezetését, így az ezt célzó befektetések indokoltnak látszanak. [62]

\section{SPORT}

Ma még csupán szűk körben ismert tény, hogy a VR-t már a sportban is alkalmazzák. A valós sportoló mozgását a virtuális térben lemodellezve és elemezve a szakemberek képesek meghatározni azokat a paramétereket, tényezőket, amelyeket változtatva lehetővé válik a versenyzők teljesítményének fokozása. Az élsportban akár már a legapróbb mozzanat, illetve azon végrehajtott változtatás is befolyással lehet egy verseny, világbajnokság vagy olimpiai döntő kimenetelére. Mivel a virtuális térben bármilyen szögből meg lehet figyelni a mozgást, így a legapróbb hibákra is fény derülhet. $A$ sérüléseket is el lehet kerülni a felkészülés során olyan sportágak esetében, ahol nagy esély van az ellenféllel történő fizikai kontaktusra, ugyanis a virtuális ellenfelekkel való esetleges összeütközések nem járnak sérüléssel. Amennyiben megfelelő anyagi forrás áll rendelkezésre a VR-rendszerek széles körű alkalmazási feltételeinek megteremtésére, olyan problémák is kiküszöbölhetők, mint az edzők vagy a sportlétesítmények hiánya, mert az edzésszimulátorok tartalmazhatnak beépített edzésprogramokat és képesek akár egy üres szobát sportpályaként megjeleníteni. [63] A VR-ral folytatott edzések azonban mostanáig még nem mindenhol váltották be a hozzájuk füzött reményeket, amelynek alapvető oka a rendszerek kiforratlansága. Ugyanakkor az eddigi tapasztalatok azt mutatják, hogy még hatalmas potenciál rejlik az ilyen típusú megoldások alkalmazásában. [64] (27. ábra.)

\section{KULTÚRA, HAGYOMÁNYŐRZÉS, RÉGÉSZET}

Társadalmaink ismert, illetve mindmáig feltáratlan történelmi és kulturális örökségét alapvetően az idő múlása, azaz a környezeti, civilizációs és szellemi eróziós folyamatok veszélyeztetik a legnagyobb mértékben. A mindennapi élet felgyorsulása, az emberi tevékenységek hatásai súlyos nyomokat hagynak bolygónk természeti és kulturális ökoszisztémájában. A légszennyezés, a háborúk, vagy akár az elsőre ártalmatlannak tűnő turizmus csak egy-egy kiragadott példa a potenciális veszélyforrások közül. A vizsgálatokat a társadalmi és gazdasági változásokra is kiterjesztve, az évtizedek óta zajló tendenciákat szemlélve nem alaptalan a félelem, hogy az idő múlásával történelmi és kulturális örökségünk még fellelhető építészeti, tárgyi emlékeinek egyre nagyobb része válik az enyészet áldozatává. Bár ezekre a problémákra nem kínál igazi megoldást a VR-technológia, de a különböző korszerű technikai eszközök segítségével technikailag megvalósítható a még fellelhető örökségünk digitális formában történő archiválása, illetve a már elpusztult építészeti és tárgyi emlékek digitális rekonstrukciója. Így a virtuális térben lehetőség nyílik az utókor számára történő megőrzésre, valamint multimédiás tartalmak, 3D-s modellek és animációk segítségével történő bemutatásra. [65] A meglévő tárgyak, épületek, romok digitalizálását többféleképpen is végre lehet hajtani. Egyik

33. ábra. Egy ásatási terület virtuális modellje [70]

megoldás, hogy különböző szögekből fotósorozatokat készítünk, amelyeken a vizsgált objektum legapróbb részletei is redundáns módon fellelhetők. Ezeket a felvételeket különböző célszoftverek segítségével feldolgozva, előállítható egy textúrázott 3D-s modell, amely a későbbiekben szabadon felhasználható, manipulálható, vagy akár animálható is. A másik megoldás elve hasonló, csak a képrögzítés folyamata és a modellalkotás is automatizáltan megy végbe különböző elektromágneses hullámhossztartományokban. A 3D-s szkennelési eljárások lényegesen nagyobb pontosságot és akár professzionális (ipari) felhasználást is lehetővé tesznek. Az elkészült digitális modellek a számítástechnika és informatika segítségével felhasználhatók az oktatásban, a kutatásban, illetve bemutathatóvá tehetők múzeumokban, vagy akár reprodukálhatók térbeli, kézzel fogható eszközként 3D-s nyomtatási technikák [66] felhasználásával. A digitális modellek testközelben történő, élményszerű bemutatásának, megjelenítésének egyik legkorszerűbb megoldását a VR/AR-technológiák alkalmazása jelenti.

Ugyanakkor a VR a kultúra- és hagyományőrzés területén felül ma már régészeti feltárások során is kínál profeszszionális megoldásokat. A digitális archiválást, a feltárt helyszínek virtualizációját és vizualizációját, illetve a leletek 3D-s modelljének előállítását a korábbiakban bemutatott módon lehet elvégezni. Ugyanakkor a nagyobb kiterjedésű ásatási területek digitalizálása esetén komoly segítséget nyújthatnak a levegőből, ma már drónok segítségével nagy tömegben készíthető, jó minőségű légi felvételek. [67] [68] A korszerű technológiának köszönhetően a feltárás digitális archiválását a munkálatok különböző fázisaiban is egyszerűen el lehet végezni, ami jelentős többletinformációt hordozhat akár az eredmények későbbi értékelése vagy új kutatási irányok kijelölése szempontjából, akár a szakmai képzések során. A leletek sok esetben hiányosak, sérültek, megrongálódtak, ilyen esetekben a 3D-s modellező programok segítségével manipulálva a feltárás során előkerült lelet állapotáról szkenneléssel ké-

34. ábra. 3D-s modellezés a régészetben [71]
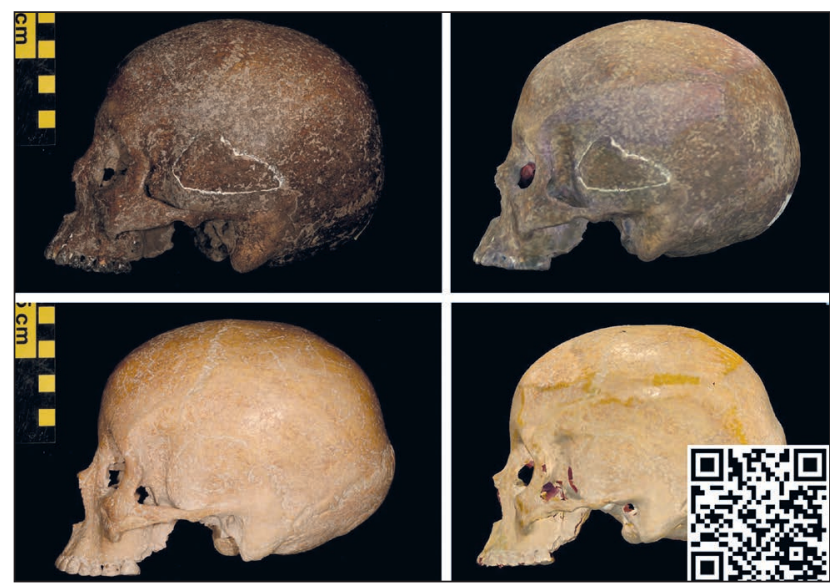
szült modellt, elvégezhető a tárgy digitális rekonstrukciója, azaz megjeleníthetővé válik az eredeti állapot. [69] Ezen alkalmazási lehetőségeket mutatja be QR-kódok beolvasásával megtekinthetővé váló két videó. A 33. ábrán egy ásatási területről „DJl Phantom 4” drónnal készített felvételekből előállított virtuális modell látható, míg a 34. ábra a 3D-s modellalkotás és a régészet kapcsolatát mutatja be egy példán keresztül.

\section{MüSZAKI KÉPZÉS, ÜZEMELTETÉS, KARBANTARTÁS, ELLENŐRZÉS}

A különböző műszaki berendezések, járművek, rendszerek megbízható és biztonságos üzemeltetéséhez elengedhetetlen az állapot és a működőképesség meghatározott időközönként történő, szakemberek által végzett ellenőrzése. Ezen munkafolyamatokat a virtuális, illetve kiterjesztett valóság alapú eszközök és megoldások egyrészt hatékonyan képesek támogatni, másrészt az új szakemberek képzésének, betanításának folyamatát is képesek jelentősen csökkenteni. Ugyanakkor a műszaki képzési terület minden szintjén (szakmunkás, technikus, mérnök) komoly támogatást nyújthatnak a különböző VR- és AR-szoftverek, amelyek segítségével virtuális 3D-s modelleken, animációkon betanulható a rendszerek felépítése, működése, illetve begyakorolhatóvá válnak a különböző feladatok, többek között az ellenőrzés és a karbantartás folyamatának egyes lépései. Az AR-vizualizáció előnye a VR-ral szemben, hogy az AR a valós környezetben jelenít meg virtuális objektumokat, nem korlátozva érdemben a felhasználó kilátását, így a valós feladatok végrehajtása során is használhatóvá válik. Egy AR-hardver segítségével a valós objektumok a virtuális objektumokkal akár össze is kapcsolhatók, ami jelentősen kiszélesíti az alkalmazás lehetőségeit. [72]

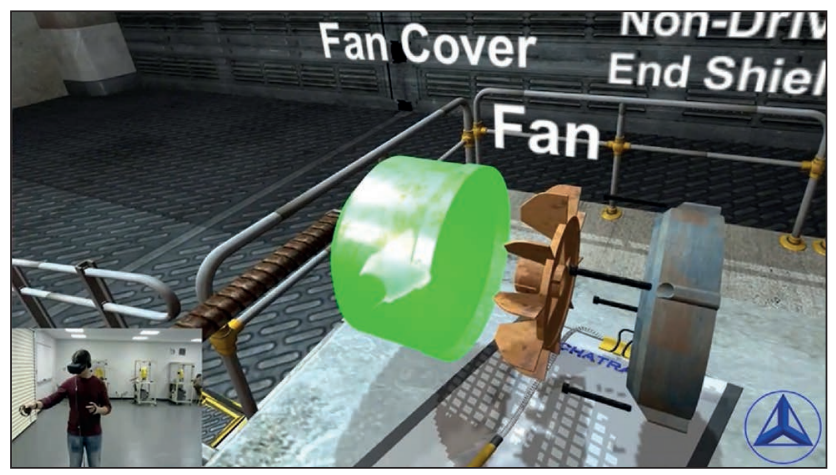

35. ábra. Müszaki képzés a virtuális valóságban [73]

\section{Összegzés}

Bár az ilyen rendszerek és módszerek alkalmazása még gyermekcipőben jár, már számos területen rendelkezünk tapasztalattal [74], amelyek kivétel nélkül a hatékonyság, eredményesség javulását támasztják alá. Ezek közül a teljesség igénye nélkül néhány példát mutatunk be, amelyek alapján érzékelhetővé válik, miben is rejlik a VR/ARrendszerek valódi jelentősége:

- Azok a sebészek, akiket VR segítségével készítettek fel egy mútétre, 29\%-kal gyorsabban és 16,6\%-kal kevesebb hibával végezték el az operációt, mint akik a hagyományos módszerrel készültek fel. [75]

- Azok a katonák, akiket egy VR-kiképzőrendszer szimulációin keresztül készítettek fel, 2,7-szer sikeresebbek voltak társaiknál. [76]
- Azok az emberek, akik a virtuális valóságban tapasztaltak meg eseményeket, 9\%-kal pontosabban és 41\%-kal kevesebb hibával tudtak felidézni részleteket, mint azok, akik csak a számítógép monitorján keresztül követték a látottakat. [77]

A VR/AR polgári alkalmazási lehetőségei tehát rendkívül kiterjedtek. Tanulmányunkban sorra vettük a legjellemzőbb területeket, amelyek természetesen csupán töredékét teszik ki a jelenlegi és jövőbeni felhasználási lehetőségeknek. A technológia fejlődésével és a piaci verseny erősödésével az ilyen megoldások egyre gyorsuló terjedése prognosztizálható, ami egyrészt elősegíti egy-egy konkrét területen alkalmazott rendszer hatékonyságának fokozását, másrészt tovább gyorsítja a technológia fejlődési ütemét. $A z$ irány, ami felé haladunk, a virtuális és a valós világ közötti határvonalak fokozatos elmosódása mind az érzékelés, mind pedig a tevékenységek területén. Az immerzivitásélmény fokozódásával a felhasználó a jövőben egyre több szállal fog kötődni a virtuális térhez, különösen akkor, ha ott számos olyan dolgot is megtapasztalhat, illetve kipróbálhat, amit a valóságban esetleg soha. Ez azonban nagyon komoly (egészségügyi, biztonsági stb.) kockázatokat is rejt magában, különös tekintettel a szabadidős célú alkalmazások esetén. Ezért is fontos, hogy a technikai dimenziók vizsgálata mellett egyre nagyobb hangsúlyt fektessünk a VR/AR terjedésének társadalmi hatásaira is. A technológia véleményünk szerint egy évtizeden belül a legtöbb szakterületen megkerülhetetlen, sőt kulcsfontosságú tényezővé válik, az orvostudomány, a műszaki tervezés, az üzemeltetés, a karbantartás, az oktatás, a képzés és a kiképzés területén egyaránt, ezért kutatása nemcsak indokolt, hanem időszerű, stratégiai jelentőségű kérdés.

A tanulmány záró részében a VR/AR katonai alkalmazási lehetőségeit mutatjuk be, amellyel nem titkolt célunk, hogy új megvilágításba helyezzük a katonai felkészítés, képzés és kiképzés aktuális kérdéseit is.

\section{(Folytatjuk)}

\section{HIVATKOZOTT IRODALOM}

[48] George Jijiashvili, „6.4 million consumer VR headsets will be sold in 2020, with content spending surpassing \$1bn mark, Omdia's new research shows." Gamasutra, 2020.11.30. https://www. gamasutra.com/blogs/GeorgeJijiashvi li/20201130/374385/64 million consumer VR headsets_will_be_sold_in_2020_with_content_ spending_surpassing_1bn_mark_Omdias_new_ research_shows.php (Letöltve: 2021.2 .2 .);

[49] Iberdrola, „Virtual Reality: another world within sight." https://www.iberdrola.com/innovation/ virtual-reality (Letöltve: 2021.2.2.);

[50] Statista, „Augmented and virtual reality (AR/VR) headset shipments worldwide from 2020 to 2025," https://www.statista.com/statistics/653390/ worldwide-virtual-and-augmented-reality-headsetshipments (Letöltve: 2021.2.2.);

[51] Tim Dams „2020 In Review: Virtual Reality Gets Real." 2020.12.10. https://www.ibc.org/trends/2020in-review-virtual-reality-gets-real/7106.article (Letöltve: 2021.2.2.);

[52] „Virtual Reality Uses in Architecture and Design.”, 2017.1.17. https://medium.com/studiotmd/ virtual-reality-uses-in-architecture-and-designc5d54b7c1e89 (Letöltve: 2021.1.16.); 
[53] Christine Hart, „,VR for Architecture: From Virtual Design to Real PR," Medium, 2018.2.26. https://medium.com/stambolstudios/vr-forarchitecture-from-virtual-design-to-real-pr66740da694e0 (Letöltve: 2020.7.13.);

[54] Kim O'Connell, „4 Tips to Get Started With Virtual Reality in Architecture," Redshift, 2016.11.16. https://www.autodesk.com/redshift/virtual-reality-inarchitecture (Letöltve: 2020.7.13.). QR-kód: „Bejárhatsz egy házat otthonról? Igen, ez is lehetséges a 3D Virtuális Ingatlansétával!" https://webseta.hu/virtualis-seta/ingatlan/kiado/ lakas/budapest/budapest-terez-korut-8-r1611222/ szoba_12/ (Letöltve: 2020.7.16.);

[55] Haruka Motomatsu. „Virtual Reality in the Medical Field." UC Merced Undergraduate Research Journal 7, no. 1 (2014): 207-217, https://escholarship.org/uc/ item/Obs5p31h (Letöltve: 2021.2.2.);

[56] „Queen's University Launches Canada's First VR Medical Training Centre," Queens University, 2018.10.09. https://healthsci.queensu.ca/node/3844 (Letöltve: 2020.7.13.);

[57] Virágh Krisztián, Harcszimulátorok integrálásának lehetőségei a hazai katonai kiképzés rendszerébe (Szakdolgozat, Nemzeti Közszolgálati Egyetem, 2020): 11. p.;

[58] Szabó András, Németh András, „A katonai műszaki képzés rendszerének kihívásai és lehetséges fejlesztési irányai", Hadtudományi Szemle XII. különszám (2019) pp. 261-288., https://doi. org/10.32563/hsz.2019.1.ksz.19;

[59] Joseph Psotka, „Immersive training systems - Virtual reality and education and training." Instructional Science 23 (1995 november): 405-431, https://doi. org/10.1007/BF00896880;

[60] Fóti Péter, „Poroszos-e a mai magyar iskolarendszer?" 2009. http://www.foti-peter.hu/porosz.html (Letöltve: 2021.1.16.);

[61] Bokros Judit, Nagy Zoltán Péter. „Kevés a pedagógus, a probléma sokrétü, az egyik ok a nyugdíjba vonulás." FEOL, 2017. 10. 0.5.

https://www.feol.hu/kozelet/helyi-kozelet/iskolapedagogusok-szakma-2111289/ (Letöltve: 2021.1.16.);

[62] „Survey Shows that Teachers See Potential for Virtual Reality in Education." Samsung, 2017.2.17. https://news.samsung.com/global/survey-showsthat-teachers-see-potential-for-virtual-reality-ineducation (Letöltve: 2021.1.16.);

[63] Hua-ping Yao, Yu-zhong Liu, Chang-song Han. „Application Expectation of Virtual Reality in Basketball Teaching." Procedia Engineering 29 (February 2012): 4287-4291,

https://doi.org/10.1016/j.proeng.2012.01.659 (Letöltve: 2021.1.16.);

[64] Adi Robertson. „VR football didn't actually help me learn football, but it's still a lot of fun." The Verge, 2017.2.04. https://www.theverge. com/2017/2/4/14503082/vr-sports-challengefootball-super-bowl (Letöltve: 2021.1.16.);

[65] András Németh, András Szabó, Ferenc Balog. „3D Virtualisation and Visualisation Technologies for Archiving the Results." In: Gábor, Hausner; András, Németh (szerk.) Zrínyi-Újvár: A Seventeenth-Century Border Defence System on the Edge of the Ottoman Empire, Budapest: Ludovika Egyetemi Kiadó, (2020) pp. 225-268.;
[66] Gál Bence, Németh András. „Additív gyártástechnológiák katonai alkalmazásának vizsgálata, különös tekintettel a katonai elektronika területére.", Hadmérnök 2019/1 pp. 231-249. http://hadmernok. hu/191_19_gal.pdf (Letöltve: 2021.1.16.);

[67] Németh András. „Technical Dimensions of the Development of Unmanned Aerial Systems and Their Impact on Public Service Uses". AARMS 2018/3. pp. 149-163.

[68] Németh András, Pápics Patrik. „Mini UAV-rajok alkalmazásának lehetőségei, különös tekintettel a katonai célú igénybevételre II. rész", Haditechnika 53 , 6. sz. (2019): 15-19. https://doi.org/10.23713/ HT.53.6.01;

[69] Víctor Manuel López-Menchero Bendicho, Mariano Flores Gutiérrez, Matthew L. Vincent, Alfredo Grande León. „Digital Heritage and Virtual Archaeology: An Approach Through the Framework of International Recommendations." In Mixed Reality and Gamification for Cultural Heritage, edited by Marinos loannides, Nadia Magnenat-Thalmann, George Papagiannakis, 3-26. Cham: Springer, 2017. https:// doi.org/10.1007/978-3-319-49607-8_1;

[70] „Using Drones for 3D site Modeling 3D Model of Archaeological Site, created with DJI Phantom 4 Drone," https://www.youtube.com/ watch? v=TK2PWXaLkVg (Letöltve: 2020.9.25.);

[71] Sabrina Sholts, „3D modeling of archaeological objects: Advantages, limitations, and applications," ArchéOrient, 2018.3.29. https://archeorient. hypotheses.org/6720 (Letöltve: 2020.9.25.). QR-kód: „3D models and archaeology.” 2019. https://www. youtube.com/watch?v=dwr9e74S_J4 (Letöltve: 2020.9.25.);

[72] Augmentor, „Understanding Augmented and Virtual Reality for Maintenance and Repair." 2020.06.09. https://goaugmentor.com/understanding-ar-and-vrtechnology/ (Letöltve: 2020. 7.13.);

[73] „Virtual Reality Motor Maintenance by Mechatraining LLC," 2017. https://www.youtube.com/ watch?v=dq2RSIsIQcU (Letöltve: 2020.9.25.);

[74] Doug Donovan, „[10 Case Studies] Virtual Reality Increases Training Effectiveness." June 09, 2018 https://www.interplaylearning.com/blog/virtualreality-increases-training-effectiveness-10-casestudies (Letöltve: 2021.1.16.);

[75] Neal E. Seymour, Anthony G. Gallagher, Sanziana A Roman, Michael K. O’Brien, Vipin K. Bansal, Dana K. Andersen, Richard M. Satava, „Virtual reality training improves operating room performance: Results of a randomized, double-blinded study." Annals of Surgery 236, no. 4 (2002): 458-63, https://www. interplaylearning.com/hubfs/Blog/Case\%20Studies/ Virtual\%20Reality\%20Improves\%200perating.pdf https.//doi.org/10.1097/01.SLA.0000028969.51489.B4;

[76] Bruce M. Perrin, Barbara J. Buck, Sara Elizabeth Gehr, „Intelligent Tutoring: Bridging the Gap from Knowing to Doing." Interservice/Industry Training, Simulation, and Education Conference (I/ITSEC), 2010. https://www.interplaylearning.com/hubfs/Blog/ Case\%20Studies/Intelligent\%20Tutoring\%20 Bridging\%20the\%20Gap\%20from\%20Knowing\%20 to\%20Doing.pdf (Letöltve: 2021.1.16.);

[77] Eric Krokos, Catherine Plaisant, Amitabh Varshney, „Virtual memory palaces: immersion aids recall." Virtual Reality 23 (2019): 1-15, https://doi. org/10.1007/s10055-018-0346-3. 